\title{
Introducing Information Technology to Palestinian Schools
}

\author{
Dr. Labib Arafeh \\ Al-Quds University, Jerusalem, Palestine
}

tarafeh@eng.alquds.edu

\begin{abstract}
The paper presents the two perspectives of IT in the Palestinian schools. The basic IT literacy - based courses have been introduced in most of private schools since 1985, and formally started in all public as well private schools in 1999. This covers eight grades from the fifth up to the twelfth. An additional two classes per week have been introduced to the weekly school program. The main objective is to create a new technological-mentality generation that understand, use, explore, and involve in the highly demanded field. Students will be facilitated with the basic IT skills to understand, use, and promote their studies in effectively understanding, searching, reporting, and documenting. Teachers badly need IT paradigms to boost their instructional materials and teaching aids. In addition to the workshops, an Arabic languagebased web site will be constructed to assist schoolteachers, administrators, and students etc. in learning technology online an offline. Further more, a collaborative Palestinian School Teachers Network (PSNET), dedicated to support teachers in developing, and enhancing computer-based instructional materials and educational aids.

Using the IT techniques in presenting instructional materials is still in its infant stage. To meet the highly demand in IT profession, higher educational institutions are badly required to update their curriculum and provide their graduates with advanced IT skills.
\end{abstract}

Keywords: IT, IT Skills, Instructional Material, K-12, Schoolteachers.

\section{Introduction}

With the recent releasing of the latest Information and Communications Technology, ICT, at an affordable price, and an enhanceable Multimedia technology, Information Technology, IT, based applications are becoming more and more feasible mainly in the developing countries. Rarely, we find an application or a field that is not related or based on IT. Education is one of these potential applications. The remarkable interest being shown in the potential role of IT in education may be due to a series of developments that can be traced back over more than three decades. These include, invention of hypertext concept; building of the physical network connections that have given rise to the world wide Internet; development of more versatile software tools for courseware authoring; development of systems for supporting the range of teaching and learning processes that comprise a complete educational program; and improvements in multimedia technology-enhanced microprocessors, computer memory, and disk technology that have enabled the sophistication of the tasks that can be carried out by computers to be greatly increased

Material published as part of these proceedings, either on-line or in print, is copyrighted by Informing Science. Permission to make digital or paper copy of part or all of these works for personal or classroom use is granted without fee provided that the copies are not made or distributed for profit or commercial advantage AND that copies 1) bear this notice in full and 2) give the full citation on the first page. It is permissible to abstract these works so long as credit is given. To copy in all other cases or to republish or to post on a server or to redistribute to lists requires specific permission from the publisher at Publister@intormingscience.org
(Potashnik, 1996, Philips 1997, Arafeh 1999).

The currently available Media \& Technologies include, Print Correspondence, CD-ROM's Interactive Disks; Instructional Radio Television / Videotape \& Interactive TV; Interactive Videodisc; Teleconferencing such as Audio teleconferencing, Audiographic, teleconferencing, and Video teleconferencing; Computer Networking; and Courseware 
(Baker 1997, Daniel 1996, Taylor 1996, Arafeh 1998, Ingles, Ling, and Joosten 1999). Basing upon this review, the technology plays an essential and a vital role in the educational activities, including course design and delivery, interaction and learning, management and organization.

Among the Palestinians, who seek jobs locally, regionally and globally, education plays a vital role in their life and tradition. This is mainly due to the facts including the occupation and the lack of natural resources. To cope with the recent advancement in the IT fields and its applications, mainly in the developed nations, Palestinians in the occupied West Bank of Jordan, Currently, Palestinian Authority, have adopted IT based and related topics in their schools' curriculums. This adoption goes back to the last two decades as illustrated in the Table I. Private schools that are governed by mainly Non Governmental Organizations, NGOs, were the pioneers in introducing, providing, adopting computer facilities and services to their students. These IT services have been used as indicators and positive marketing measures that reflect the quality of teaching schools offer (Arafeh, 1999).

Two major folds were considered while introducing IT to schools. The first one is to introduce literacy basic skills for students to understand and utilize IT. After which, students will be able to use computers

\begin{tabular}{|c|c|c|c|c|c|c|}
\hline Period & IT Services & $\begin{array}{l}\text { Teaching IT } \\
\text { Skills }\end{array}$ & Using IT in Education & $\begin{array}{l}\text { Local Accredited } \\
\text { IT Programs }\end{array}$ & $\begin{array}{l}\text { Political } \\
\text { Status }\end{array}$ & Comments \\
\hline $\begin{array}{c}1985 \\
\text { to } \\
1991\end{array}$ & PCs & $\begin{array}{l}\text { DOS, BASIC, Word } \\
\text { Processors, Spread- } \\
\text { sheets Problem Solv- } \\
\text { ing using computers }\end{array}$ & $\begin{array}{l}\text { Very few bought English } \\
\text { Language-based Pro- } \\
\text { grams used for demon- } \\
\text { stration, simple developed } \\
\text { administrative programs }\end{array}$ & $\begin{array}{l}\text { One B.Sc. Program } \\
\text { Four 2-year Diploma }\end{array}$ & $\begin{array}{l}\text { Under Occupa- } \\
\text { tion }\end{array}$ & $\begin{array}{l}\text { Private Schools, } \\
\text { Students' Age is } \\
14 \text { to } 16 \text { Years, } \\
\text { Non-standard Syl- } \\
\text { labus }\end{array}$ \\
\hline $\begin{array}{l}1991 \\
\text { to } \\
1994\end{array}$ & $\begin{array}{l}\text { PCs, Net- } \\
\text { works }\end{array}$ & $\begin{array}{l}\text { DOS, Windows, } \\
\text { BASIC, Word Proc- } \\
\text { essors, Spreadsheets, } \\
\text { Database, Problem } \\
\text { Solving using com- } \\
\text { puters }\end{array}$ & $\begin{array}{l}\text { Bought English Lan- } \\
\text { guage- based Programs } \\
\text { used in teaching Math, } \\
\text { English Language, menu- } \\
\text { driven developed admin- } \\
\text { istrative programs }\end{array}$ & $\begin{array}{c}\text { Two B.Sc. Programs } \\
\text { Eight 2-year Di- } \\
\text { ploma }\end{array}$ & $\begin{array}{l}\text { Under Occupa- } \\
\text { tion }\end{array}$ & $\begin{array}{l}\text { Private Schools, } \\
\text { Students' Age is } \\
\text { 10-16 Years, Non- } \\
\text { standard Syllabus }\end{array}$ \\
\hline $\begin{array}{l}1994 \\
\text { to } \\
2001\end{array}$ & $\begin{array}{c}\text { PCs, Net- } \\
\text { works, Inter- } \\
\text { net }\end{array}$ & $\begin{array}{c}\text { Windows, C, Visual } \\
\text { BASIC, Word Proc- } \\
\text { essors, Spreadsheets, } \\
\text { Database, Internet } \\
\text { Browsers, Web Page } \\
\text { developing packages, } \\
\text { Problem Solving } \\
\text { using computers }\end{array}$ & $\begin{array}{l}\text { Mainly bought, \&few } \\
\text { developed Arabic / Eng- } \\
\text { lish Multimedia-based } \\
\text { Programs used in teaching } \\
\text { Science, Math, A/E Lan- } \\
\text { guages, etc. User-friendly } \\
\text { administrative programs }\end{array}$ & $\begin{array}{c}\text { Five B.Sc., one } \\
\text { M.Sc. Programs } \\
\text { Sixteen 2-year Di- } \\
\text { ploma }\end{array}$ & $\begin{array}{c}\text { Palestinian } \\
\text { Authority }\end{array}$ & \begin{tabular}{|} 
Private Schools, \\
Nurseries, and \\
Students' Age is 8- \\
16 Years \\
Public Schools, \\
Regular Students' \\
Age is 10-12 \\
Years, and techni- \\
cal Students' Age \\
is 16-18 Years, \\
Partially standard \\
Syllabus
\end{tabular} \\
\hline $\begin{array}{l}2002 \\
\text { to } \\
2005\end{array}$ & $\begin{array}{c}\text { PCs, Net- } \\
\text { works, Inter- } \\
\text { net, PSNET }\end{array}$ & $\begin{array}{c}\text { Windows, C, Java, } \\
\text { Visual BASIC, Word } \\
\text { Processors, Spread- } \\
\text { sheets, Database, } \\
\text { Email, Graphics, } \\
\text { Internet Browsers, } \\
\text { Web Page develop- } \\
\text { ing packages, OO } \\
\text { Problem Solving } \\
\text { approach }\end{array}$ & $\begin{array}{l}\text { Few bought, \& mainly } \\
\text { Collaborate- developed } \\
\text { Arabic / English Pro- } \\
\text { grams used for teaching } \\
\text { Arts, Science, Math, A/E } \\
\text { Languages, etc. }\end{array}$ & $\begin{array}{c}\text { Six B.Sc., Two } \\
\text { M.Sc. Programs } \\
\text { Twenty 2-year Di- } \\
\text { ploma }\end{array}$ & $\begin{array}{l}\text { Palestinian } \\
\text { State (hope- } \\
\text { fully) }\end{array}$ & $\begin{array}{c}\text { Private Schools, } \\
\text { Nurseries, Stu- } \\
\text { dents' Age is 8-18 } \\
\text { Years } \\
\text { Public, } \\
\text { Regular Students' } \\
\text { Age is 10-18 } \\
\text { Years, and techni- } \\
\text { cal Students' Age } \\
\text { is 16-18 Years, } \\
\text { Mainly Standard } \\
\text { Syllabus }\end{array}$ \\
\hline
\end{tabular}


to enhance their studies in searching, reporting, documenting, etc. The second fold is to train teachers how to enhance their instructional materials and teaching aids using IT tools and paradigm.

\section{Standardized IT Courses}

A ten-year project, sponsored by the EC, has been implemented by the Ministry of Education Curriculum Development Department to rewrite and update all schools' syllabus and textbooks; and introduce the technology related topics to the Palestinian public schools starting from the $5^{\text {th }}$ grade up to the $12^{\text {th }}$ one. Two-hour consecutive classes per week have been (approximately $6 \%$ of the total classes taken by students) introduced to the weekly school timetable. The main objective is to create a new technologicalmentality generation that understand, use, explore, and develop. The core of the curriculum covers several major topics including Computer Science concepts and applications, Energy, Drawing, Disassembly and Assembly, Design and Science Fiction, Communication, and Projects. The IT-based topics consume approximately $60-70 \%$ of the total topics to be covered. The various stages in developing IT related school textbooks include:

1. Setting up the very clearly major objectives and a scope and sequence for the skills that are to be taught and curriculum outlines for the eight grades. All these are grade and age specific. This stage includes establishing the Technology National Curriculum Committee, reviewing the curriculum by a technical reviewing committee, approving the outlines by the Ministry of Education, and setting a plan for developing School Textbooks.

2. Starting with developing fifth, sixth, and seventh grades textbooks. Currently, we are developing concurrently, the eighth, ninths, and tenth grades textbooks. This stage includes iterative writing new instructional materials, reviewing them technically, syntactically, and grammatically, designing textbooks, publishing and distributing them to schools.

3. Performing several introductory workshops every year dedicated towards teachers who will teach the technology topics in schools.

4. By the end of the year, 2002, all technology textbooks to all grades will be provided.

5. Comments and fed back notes coming from various users of these textbooks along with updating parts of the material will be taken into account in the next print versions.

\section{IT School Website}

A dedicated Arabic language-based web site is intended to construct in order to assist schoolteachers (K12 teachers), administrators, and students etc. in learning tools technology synchronously and asynchronously. Several electronic-based resources, tools, software support, tutorials and manuals will be included in this web site. Thus, it will enable some of the academic processes and help establish an academy to train teachers on IT skills and how to use the Internet in enhancing the teaching process.

The various features and claimed advantages of enhancing instructional materials with IT tools include (Lochte 1993, Daniel 1996, Agnew 1996, Potashnik 1996, Baker 1997, Hazemi, 1998, Arafeh 1999), Demonstrable improvements in student academic achievement; More cost-effective applications of technology; Innovative solutions to current and instantaneous challenges; Ensured consistency, reliability, and quality in instruction, assessment, and feedback; Reduced learning time; On-demand learning; Increased achievement; Greater flexibility and seamless access; Faster revision; Student controlled; Maintained and published easily; Very close to Natural Interface (Face - to -Face Communications).

There are two modes of delivery, the synchronous (Real time / Online) such as Chatting, Conferencing (Audio/Video), and Whiteboard to share text and diagrams; the second mode is the Asynchronous (Offline / Students' own times), such as Telephone, Fax, Mail; CD-ROM Interactive Disks Bulletin Board; 
Introducing Information Technology to Palestinian Schools

Email; Newsgroup, and Mailing Lists; Internet Downloading Materials. The various IT related topics and tools that might be included are as listed in Table II (Arafeh 2001).

\begin{tabular}{|c|c|c|}
\hline Computer Skills & Simple Required Software & Remarks \\
\hline $\begin{array}{c}\text { Basic Skills } \\
\text { Operating System } \\
\text { Word Processing } \\
\text { Spread Sheets } \\
\text { Internet } \\
\text { Email } \\
\\
\text { S/W Installation } \\
\text { Simple HW Installation } \\
\text { Simple Graphics } \\
\text { Notebook }\end{array}$ & $\begin{array}{c}\text { Windows }(98,2000, \mathrm{NT}, \mathrm{XP}) \\
\text { Word } \\
\text { Excel } \\
\text { Internet Explorer } \\
\text { Navigator } \\
\text { Outlook } \\
\text { Messenger } \\
\text { Windows } \\
\text { Windows } \\
\text { Paint (Windows) } \\
\text { Calendar (Windows) }\end{array}$ & $\begin{array}{c}\text { PCs' Operating Systems } \\
\text { MS Office (97/2000/2002/ XP) } \\
\text { MS Office } \\
\text { MS Office } \\
\text { Netscape Communicator } \\
\text { MS Office } \\
\text { Netscape Communicator } \\
98,2000, \text { NT, XP } \\
98,2000, \text { NT, XP } \\
98,2000, \text { NT, XP } \\
98,2000, \text { NT, XP }\end{array}$ \\
\hline $\begin{array}{c}\text { Intermediate Skills } \\
\text { Programming in C, JAVA, } \\
\text { FORTRAN, Visual BASIC. } \\
\text { Compression }\end{array}$ & $\begin{array}{l}\text { Suitable Compiler } \\
\text { Winzip }\end{array}$ & \\
\hline 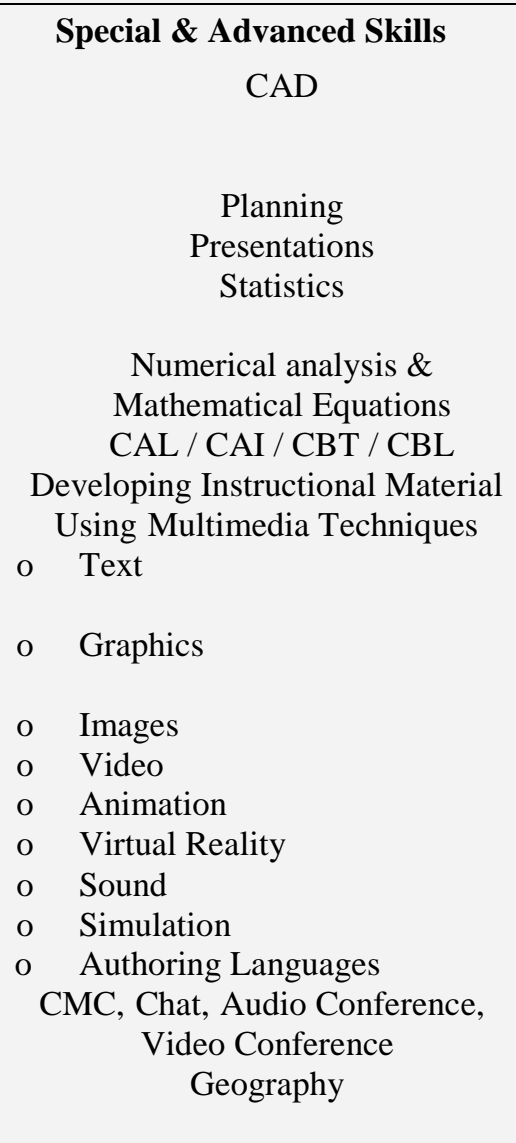 & $\begin{array}{c}\text { Word } \\
\text { Acrobat Reader/W } \\
\text { PhotoDraw } \\
\text { Photoshop } \\
\text { Photo Editor } \\
\text { Premier } \\
\text { GifAnimator, Matlab } \\
\text { Studio 3D Max } \\
\text { Sound Recorder, SoundForge } \\
\text { Director, and Matlab } \\
\text { FrontPage, Director } \\
\text { MS Netmeeting } \\
\text { GIS }\end{array}$ & $\begin{array}{c}\text { MS Office } \\
\text { Adobe } \\
\text { MS Office } \\
\text { Adobe } \\
\text { MS Office } \\
\text { Adobe } \\
\text { Windows } \\
\text { Adobe } \\
\\
\text { Macromedia, Matlab } \\
\text { MS Office, Macromedia } \\
\text { MS Office }\end{array}$ \\
\hline
\end{tabular}

Basing upon these reviews and the highly demand on IT professionals, the Palestinian higher educational institutes have increased their IT-based programs as shown in table I. In fact, using IT techniques in education is still in its initial stage. Several local IT-based institutes and centers separately and collaborately with other educational institutions have started exploring and developing IT-based tutorials and instruc- 
tional materials in both Arabic and English language. Several fields have been explored including Languages, Math, Physics, Chemistry, history, tourism, etc.

\section{PSNET}

The last stage in this long-term project is to establish an Arabic collaborative Palestinian School Teachers Network (PSNET), dedicated to manage, utilize, and coordinate all efforts in developing computer-based instructional materials and educational aids. It is required to set up, gradually, IT labs for students in all public and private schools in Palestine. Teachers from different schools connect and communicate through Internet activities and discuss relevant issues. In fact, Teachers knowledgeable about options in the traditional classroom are often unfamiliar with the learning process options available on the web, and should be given time and support to explore these opportunities. Because of the diverse skills needed for effective IT-based course or simulation development, it is advisable to use a team. PSNET will offer a badly needed and reliable means for teachers to develop collaboratively, encourage and exchange views (Falk 1997, Hazemi 1998, Arafeh, Hachisho, NourEldin, 1999, Arafeh 1999). Currently, this stage is not feasible due to the limited communications options that might be implemented, as it is highly dependent on the political situation.

\section{Conclusion}

Introducing Information Technology to schools provides students with various skills that enables them to understand and use IT means such as computers to enhance their studies in searching, reporting, documenting, etc. The teachers need IT means to make use of and enhance their instructional materials and teaching aids. IT has been first introduced in private schools in 1985. Up to 1994, IT has been adopted in some of Palestinian schools' courses in a non-standard format.

A long-term project sponsored by the EC, the Palestinian Authority has planned to introduce the technology topics to the Palestinian public schools starting from the $5^{\text {th }}$ grade up to the $12^{\text {th }}$ one. Approximately $6 \%$ of the total classes taken by students has been introduced to the weekly school program. The main objective is to create a new technological-mentality generation that understand, use, explore, and build. The first stage is concerned with developing textbooks, and performing several workshops for teachers who are supposed to teach the technology topics.

The next stage is to develop an Arabic language-based web site to assist schoolteachers, administrators, and students in learning technology online. Several electronic-based resources, tools, software support and manuals will be included in this web site.

The last stage in this long-term project is to establish a collaborative Palestinian School Teachers Network (PSNET), dedicated to manage, utilize, and coordinate all efforts in developing computer-based instructional materials and educational aids. Higher educational institutions must be aware of the IT facilities their graduates should have in order to meet the highly demanded IT professionals and facilitators.

\section{References}

Agnew P. (1996), Distributed Multimedia: Technology, applications, and opportunities in the digital information industry, New York, ACM Press.

Anderson, T., (1994), Using the Internet for distance education delivery and professional development, Open Praxis, Vol. 2.

Arafeh, L. (1998) AlqudsNet: A Challenge For The Future, Proc. $5^{\text {th }}$ Conference on Computer Communications, pp. 149-156, Tunisia.

Arafeh, L. (1999), Information and Communication Technologies in Higher Education, the $3^{\text {rd }}$ Conference of Information Technology in Higher Education, Birzeit University, Palestine. 
Introducing Information Technology to Palestinian Schools

Arafeh, L., Hachisho, O., NourEldin, H, (1999), Alquds Virtual University: A Challenge for the future, ICDE’99, u1a000556, Vienna.

Arafeh, L, (1999), Internet - Based Computer Course, Information Technology for Distance Education Conference, Al-Quds Open University, Amman.

Arafeh, L., (2001), IT skills required by university graduates, a workshop entitled "IT Enhanced Curriculum", Al-Quds University, Palestine.

Baker, W., (1997), From theory to implementation: The Mediated Learning approach to Computer - Mediated instruction , Learning and assessment", Educom Review, 32 (5), Sept./Oc.

Daniel, J. (1996), The Multi-Media Mega-University: The Hope for the $21^{\text {st }}$ Century, North of England Education Conference, Sheffield, UK.Ingles, A., Ling, P., and Joosten, V. (1999), Delivering Digitally: Managing the transition to the Knowledge Media, Kogan Page.

Falk, D., (1997), Designing a course on the world wide web, Journal of Interactive Instruction Development, Spring.

Hazemi, R., (1998), The Digital University: Reinventing the Academy, Springer, UK.Philips R.,(1997) The Developer's Handbook to Interactive Multimedia: A Practical Guide for Educational Applications, Kogan Page.

Lochte, R. (1993), Interactive Television and Instruction, Englewood Cliffs, NJ., Educational Technology Publications.

Potashnik, M., (1996), Distance Education: Lessons from Experience Challenges for the Future", Unicef Regional Seminar / Workshop on Multi Channel Learning in Cairo, Egypt.

Taylor, J., (1996), Perspectives on the educational uses of technology, Open Praxis, Vol. 2.

\section{Biography}

Labib Arafeh received the B.E. degree in Electronics from the University of Bangalore, India, in 1980, the M.Sc. degree in Computer Studies from the University of Essex, UK, in 1984, and Ph.D. degree in Intelligent Systems, from the University of Manchester Institute of Science and Technology, (UMIST), UK, 1992. He was with Electrical and Computer Engineering Department, Palestine Polytechnic, Palestinian Authority, from 1982-1998. He joined Al-Quds Open University as the director of Technology and Applied Sciences, Jerusalem, in 1998-2000. Presently, he is the chairman of the Computer Engineering Department at Al-Quds University in Jerusalem, Palestine. His areas of interest include, Multimedia, Development of Instructional Materials, Intelligent Systems, and adopting of Neurofuzzy modeling techniques in various applications. 